\title{
Effects of the Simulated Drift of Ripeners on Eucalyptus urograndis
}

\author{
Rodrigo Neto Pires ${ }^{1}$, Fernanda Campos Mastrotti Pereira ${ }^{1}$, Mariluce Pascoina Nepomuceno ${ }^{1} \&$ \\ Pedro Luis da Costa Aguiar Alves ${ }^{1}$ \\ ${ }^{1}$ College of Agricultural and Veterinary Sciences, Jaboticabal, Sao Paulo State, Brazil \\ Correspondence: Rodrigo Neto Pires, Faculdade de Ciências Agrárias e Veterinárias (FCAV - UNESP), \\ Jaboticabal, SP, Brazil. Tel: 55-16-3209-2620 ext. 218. E-mail: rodrigo_ata@hotmail.com
}

$\begin{array}{lc}\text { Received: August 22, } 2013 & \text { Accepted: September 27, } 2013 \quad \text { Online Published: November 15, } 2013 \\ \text { doi:10.5539/jas.v5n12p78 } & \text { URL: http://dx.doi.org/10.5539/jas.v5n12p78 }\end{array}$

\begin{abstract}
The objective of this study was to evaluate the effects of the drift of ripeners (sulfometuron-methyl, ethephon and trinexapac-ethyl) on the initial growth of Eucalyptus urograndis. The experimental design was a randomized block with seven treatments (control; sulfometuron-methyl 0.9 and $1.2 \mathrm{~g}$ i.a. $\mathrm{ha}^{-1}$; ethephon 28.8 and $38.3 \mathrm{~g}$ i.a ha ${ }^{-1}$; trinexapac-ethyl 15 and $20 \mathrm{~g}$ i.a. ha $^{-1}$ ) with four replicates using each plant as an experimental plot. We evaluated the effects $7,14,21,28,35$ and 42 days after application, when we determined the length, diameter, total leaf area and total dry mass of the stem. The application of sulfometuron-methyl may have resulted in an effect known as "hormesis" due to an increasing trend in stem growth. The application of trinexapac-ethyl resulted in greater increases in the leaf dry mass and leaf area compared with those caused by the other ripeners that were used in this study, most likely due to the loss of apical dominance. The application of ethephon had no significant effect on the plants.
\end{abstract}

Keywords: sulfometuron-methyl, ethephon, trinexapac-ethyl, hormesis

\section{Introduction}

Eucalyptus is the most widely planted tree in the world, with more than 17.8 million hectares. Brazil is a major host of Eucalyptus in terms of planted area, with more than five million hectares (Associação Brasileira de Produtores de Florestas Plantadas [ABRAF], 2013). Due to favorable environmental conditions, silvicultural technique and management changes, and genetic improvement, the Brazilian eucalyptus forests are among the most productive in the world and provide the qualities that are needed for the different industrial uses of wood (Tonini et al., 2004). Thus, the planting of eucalyptus has increased over the years. Similarly, the cultivation of sugar cane is also expanding.

According to the (Instituto Brasileiro de Geografia e Estatística [IBGE], 2013), Brazil is the largest producer of sugar cane, with a harvested crop area in 2011/12 of approximately 9.4 million hectares. The expansion of these crops occurs in areas (particularly small farms and deforested areas) that were previously occupied by other, less profitable crops. As a result, these crops are often grown in close proximity, especially in the state of Sao Paulo.

Due to the proximity of eucalyptus crops to sugarcane crops and the important role that eucalyptus cultivation plays in the forest sector and in the economy, the factors that influence or compromise the cultivation of these crops must be monitored. Among these factors, the spraying of pesticides deserves attention as pesticides are widely used in the cultivation of intensive crops, such as sugar cane. Non-targeted crops can also be affected due to failures in the pulverization process or to the characteristics of the products that are used.

Drift, defined as the displacement of spray pesticides outside the desired target due to wind, runoff or product volatilization (Associação Nacional de Defesa Vegetal [ANDEF], 2004), is an important flaw of such sprays, as the drift of products to non-targeted crops can damage or promote abnormalities in the plants. In the cultivation of sugarcane, the chance of drift to adjacent crops is great, as most of the applications are performed by aircraft (Durigan, 1989).

Plant regulators, such as trinexapac-ethyl, sulfometuron-methyl and ethephon, among others, can also be applied by spraying; these products are used to promote the early and accelerated maturation of sugarcane, as well as to reduce its vegetative growth. As previously mentioned, due to the proximity of these crops in the field, the drift of these ripeners may affect the development of the eucalyptus plantations. 
"Hormesis" (derived from "hormaein", which in Greek means "to excite") was originally defined as a behavior in which a biological trait is stimulated by low doses of a compound and inhibited by high doses of the same compound (Bukowski \& Lewis, 2000; Calabrese \& Baldwin, 2001; Calabrese \& Baldwin, 2002). This effect has been observed in bacteria, fungi, higher plants and animals (Calabrese, 2005).

There are no specific detailed studies regarding the effect of the drift of ripeners on eucalyptus plantations, which motivated this work. Therefore, this study aimed to evaluate the effects of sub-doses of sulfometuron-methyl, ethyl-trinexapac and ethephon on eucalyptus plants to quantify the effects of possible drift.

\section{Material and Methods}

\subsection{Local and Sample Characterization}

This work was conducted under field conditions with no water restriction from January to December 2011 at FCAV- UNESP $\left(21^{\circ} 15^{\prime} 22^{\prime \prime} \mathrm{S}, 48^{\circ} 18^{\prime} 58^{\prime \prime} \mathrm{W}\right.$ and 595 masl). The pre-selected seedlings from a hybrid of Eucalyptus grandis W. Hill ex. Maiden with E. urophylla S.T. Blake (E. urograndis) were transplanted to plastic pots $(19 \times 25 \times 14 \mathrm{~cm})$. This commercial hybrid was chosen because it is widely grown in the state of Sao Paulo, Brazil, and has a rapid growth rate, tolerance to drought periods and good wood quality.

The pots were filled with soil from the surface of a clayey red Latosol with $\mathrm{pH}$ 6.8. Minerals were provided to the seedlings fortnightly using $300 \mathrm{~kg} \mathrm{ha}^{-1}$ of the formula 4-14-8 (NPK formulation).

\subsection{Treatments and Application Method}

The treatments consisted of the sub-lethal (approximately 5 to $10 \%$ of the manufacturer-recommended dose) application of ripeners that are used in the cultivation of sugarcane to simulate the effect of a drift in the field during pesticide application. In total, seven experimental treatments were evaluated: control, sulfometuron-methyl $\left(\right.$ Curavial $\left.^{\circledR}\right)\left(0.9\right.$ and 1.2 g i.a. ha $\left.^{-1}\right)$, Ethephon $\left(\right.$ Ethrel $\left.^{\circledR}\right)\left(28.8\right.$ and 38.3 g i.a. ha $\left.{ }^{-1}\right)$, trinexapac-ethyl (Moddus $\left.{ }^{\circledR}\right)(15$ and 20 g i.a. ha $\left.{ }^{-1}\right)$.

Upon application, the average height and stem diameter of the plants were $40 \mathrm{~cm}$ and $4.5 \mathrm{~cm}$, respectively. The treatments were applied using a $\mathrm{CO}_{2}$ constant pressure backpack sprayer (model XR 11002 calibrated at a pressure of 3 bars) with spray nozzles. The applied spray volume was $200 \mathrm{~L} \mathrm{ha}^{-1}$ at a working height of $0.5 \mathrm{~m}$ above the plant to reach the entire canopy of seedlings.

\subsection{Experimental Design and Evaluations}

The experimental design was a randomized block with four replicates. Each experimental unit consisted of one plant per pot.

The treatment effects were evaluated 7, 14, 21, 28, 35 and 42 days after application (DAA), when the height (the distance from the ground to the apical bud) and stem diameter ( $5 \mathrm{~cm}$ from the ground) were measured.

At 42 DAA, in addition to the features mentioned above, the total leaf area (LiCor, LI mod 3000A) and the total, leaf and stem dry weights were determined. To obtain the dry weights, the plant material was dried in an oven with forced air circulation at $70^{\circ} \mathrm{C}$ until a constant weight was reached, and then a precision balance $0.001 \mathrm{~g}$ was used.

The height, diameter and plant dry masses were transformed to percentages, considering the control (plants that were exempted from the ripener application) as $100 \%$. These variables were fitted to the model described in the linear equation:

$$
y=a+b^{*} x
$$

The results were submitted to regression analysis (MicroCal Origin, v. 8).

\section{Results and Discussion}

\subsection{Sulfometuron-Methyl}

For the plant height, the effects of the different doses of applied sulfometuron-methyl were similar to those of the untreated control (Figure 1A).

The regression analysis (Table 1$)$ demonstrates that the initial estimate for the height of the control plants $(2.95 \mathrm{~cm}$ $\pm 114.95)$ was higher than that of the plants that were treated with two doses of sulfometuron-methyl, which did not differ from each other $(97.27 \pm 2.58 \mathrm{~cm}$ on average).

However, after the sulfometuron-methyl treatment, regardless of the dose, the growth rate of these plants increased, where each elapsed day resulted in a gain of $1.36 \pm 0.1 \mathrm{~cm}$ in height. In the control plants, this increase was $0.95 \mathrm{~cm}$ $\pm 0.09 \mathrm{~cm} \mathrm{day}^{-1}$; therefore, after 42 days, the heights of all of the plants equalized. 
For the stem diameter, the effects of the different doses of applied sulfometuron-methyl were similar to those of the untreated control (Figure 1B) during the evaluation period. Although the estimated stem diameter of the control $(8.40 \pm 0.03 \mathrm{~mm})$ was smaller than that of the plants that were treated with sulfometuron-methyl, regardless of dose $(9.98 \pm 0.44 \mathrm{~mm}$, average), no significant differences were observed 42 days after product application.
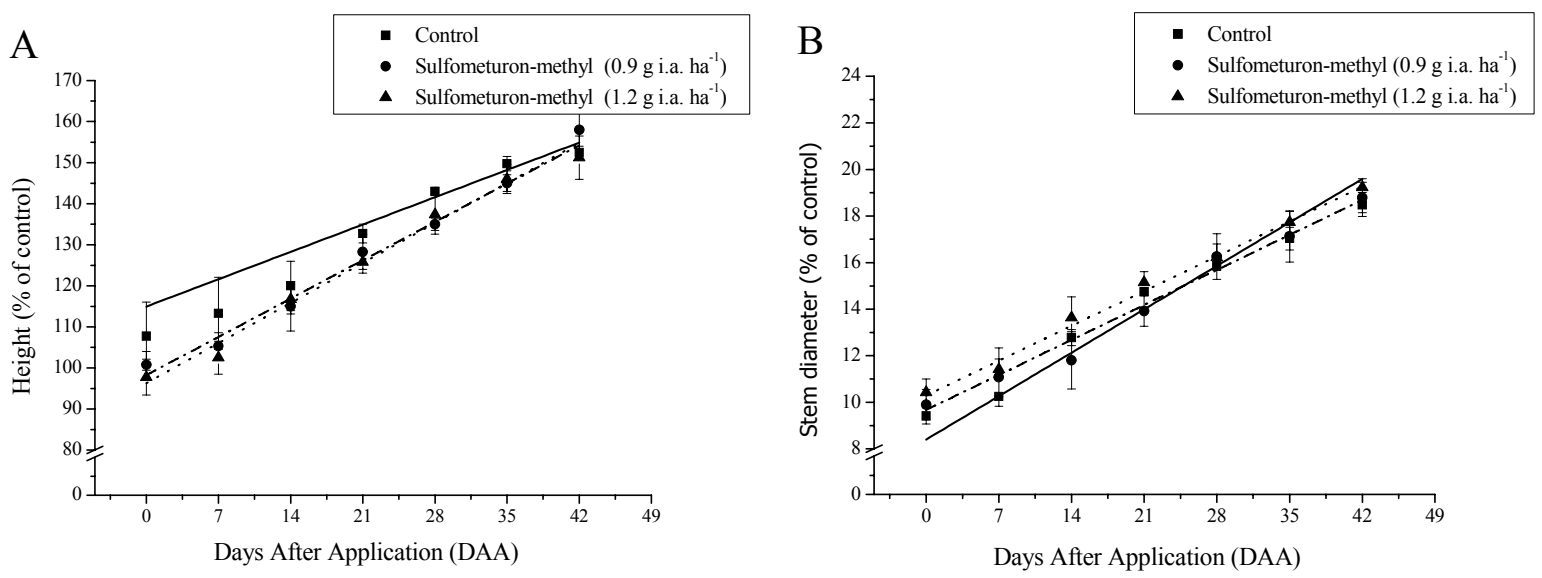

Figure 1. Effects of the different doses of sulfometuron-methyl on the height (A) and stem diameter (B) of eucalyptus seedlings up to 42 days after application (Jaboticabal, 2013)

Table 1. Parameters of the linear equation ( $\mathrm{a}$ e b) adjusted for treatment with sulfometuron-methyl, with a coefficient of determination $\left(\mathrm{R}^{2}\right)$ and $\mathrm{F}$ value for the regression analysis of variance (Jaboticabal, 2013)

\begin{tabular}{|c|c|c|c|c|}
\hline Treatment & $\mathrm{a}$ & $\mathrm{b}$ & $\mathrm{R}^{2}$ & $\mathrm{~F}$ \\
\hline \multicolumn{5}{|c|}{ Height $(\mathrm{cm})$} \\
\hline Control & $114.95 \pm 2.95$ & $0.95 \pm 0.09$ & 0.90 & $<0.001$ \\
\hline Sulfometuron-methyl (0.9 g i.a. ha $\left.^{-1}\right)$ & $98.24 \pm 2.38$ & $1.33 \pm 0.08$ & 0.90 & $<0.001$ \\
\hline Sulfometuron-methyl $\left(1.2\right.$ g i.a. $\left.\mathrm{ha}^{-1}\right)$ & $96.30 \pm 2.79$ & $1.39 \pm 0.12$ & 0.99 & $<0.001$ \\
\hline \multicolumn{5}{|l|}{ Stem diameter $(\mathrm{mm})$} \\
\hline Control & $8.40 \pm 0.03$ & $0.27 \pm 0.001$ & 0.99 & $<0.001$ \\
\hline Sulfometuron-methyl (0.9 g i.a. ha $\left.^{-1}\right)$ & $9.67 \pm 0.54$ & $0.21 \pm 0.02$ & 0.98 & $<0.001$ \\
\hline Sulfometuron-methyl (1.2 g i.a. ha $\left.^{-1}\right)$ & $10.29 \pm 0.34$ & $0.21 \pm 0.01$ & 0.99 & $<0.001$ \\
\hline
\end{tabular}

Obs: $\mathrm{a}=$ linear coefficient; $\mathrm{b}=$ angular coefficient of equation; $\mathrm{y}=\mathrm{a}+\mathrm{bx}$.

When comparing the effects of the different doses of sulfometuron-methyl, treatment with the highest dose of sulfometuron-methyl caused an increased stem diameter compared to that of the untreated control. However, the lowest dose did not result in a behavior that was different from that of the control (Figure 2).

For the plant height, there were no significant effects between the different doses of sulfometuron-methyl and the control (Figure 2).

The different doses of applied sulfometuron-methyl affected the leaf area, leaf dry mass and total dry mass of the eucalyptus plants (Figure 2). With the lowest dose of sulfometuron-methyl, the total leaf area showed a greater increase compared to that of the plants that were treated with the higher doses and that of the untreated control. Both of the doses caused an increase in these parameters compared to those of the control, but without differentiating between the parameters. For the dry mass of the stem, only the lowest dose resulted in an increase, while the effect of the higher dose did not differ from that of the untreated control (Figure 2).

Sulfometuron-methyl is an inhibitor of plant growth (Vidal, 1997). However, in this work, this ripener may have acted differently; instead of slowing down the growth rate of the eucalyptus plants, it may have led to an increasing trend in their development. 


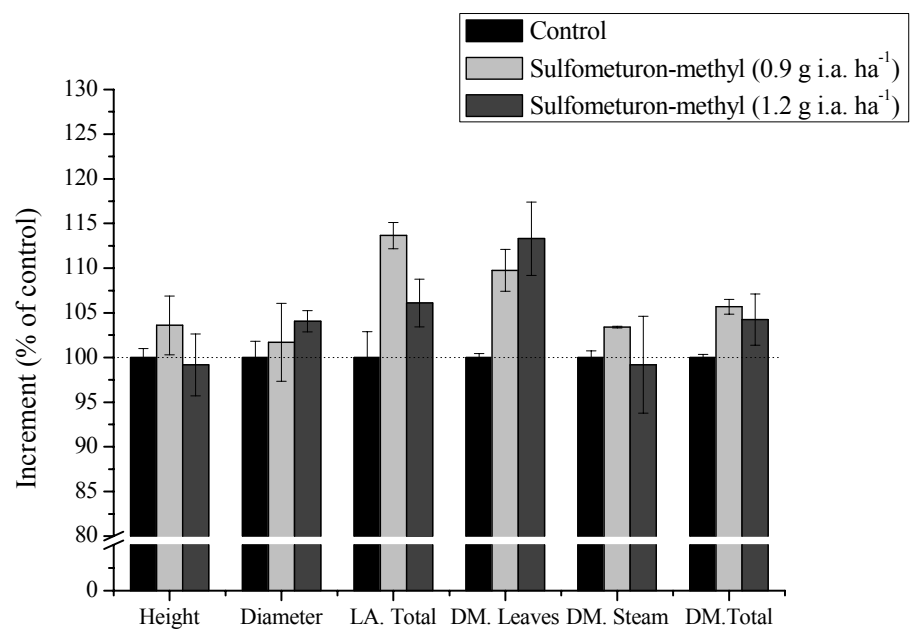

Figure 2. Effects of the different doses of sulfometuron-methyl on the height, stem diameter, leaf area and dry mass of the leaves, stem and whole plant, expressed in percentage increments (Jaboticabal, 2013)

This development can be related to the increased growth rate and the increased total leaf area, dry mass of leaves and total dry mass through an effect called "hormesis", which is defined as the promoting effect of small doses of substances of which high doses become inhibitory.

Some authors mention that low doses of glyphosate can stimulate the growth of plants (Duke et al., 2006; Cedergreen et al., 2007; Velini et al., 2010). Velini et al. (2008) observed the stimulation of the shoot growth of soybean, eucalyptus, corn, pine, coffee and citrus with glyphosate (which was applied to simulate drift) rates below $36 \mathrm{~g} \mathrm{ha}^{-1}$.

Similarly, Cedergreen (2008) found that glyphosate and sulfometuron-methyl can induce an increase in barley biomass by approximately $25 \%$ when applied at doses of $5-10 \%$ of the commercial dose, similar to the dosages that were used in this study.

\subsection{Ethephon}

For the plant height, different effects were observed between the different doses of ethephon and the untreated control (Figure 3A).

After submitting these data to a regression analysis (Table 2), it was verified that the initial heights of the plants were different, and the control plants were taller $(114.95 \pm 2.95 \mathrm{~cm})$ than the plants that received the highest dose of ethephon $(97.82 \pm 2.16 \mathrm{~cm})$, while the lowest dose showed an intermediate height $(100.00 \pm 4.57 \mathrm{~cm})$ that did not differ between the treatments.

Throughout the experiment, the increase in the height of the control plants $\left(0.95 \mathrm{~cm} \pm 0.09\right.$ day $\left.^{-1}\right)$ was similar to that of the plants that were treated with the highest dose of ethephon $\left(1.11 \pm 015\right.$ days $\left.\mathrm{cm}^{-1}\right)$ but shorter than that of the plants that were treated with the lower dose $\left(1.31 \mathrm{~cm} \pm 0.19 \mathrm{day}^{-1}\right)$; after 42 days, the heights of the plants were equalized in these two treatments, while that of the control remained higher than that of the plants that were treated with the highest dose of ethephon.

Regarding the stem diameter, similar effects were produced by the different doses of ethephon and the untreated control (Figure 3B). The regression analysis (Table 2) revealed that the estimated stem diameter of the control plants $(8.40 \pm 0.03 \mathrm{~mm})$ was lower than that of the plants that were treated with both doses of ethephon, which did not differ between each other $(9.64 \pm 0.20 \mathrm{~mm}$ on average $)$.

However, after ethephon treatment, the increase in the stem diameter of the control plants $\left(0.27 \mathrm{~mm}\right.$ day $\left.^{-1}\right)$ was higher than that of the treated plants, regardless of the dose $\left(0.24 \mathrm{~mm} \mathrm{day}^{-1}\right.$ on average $)$, causing equalization of the stem diameter of all of the plants 42 days after application. 

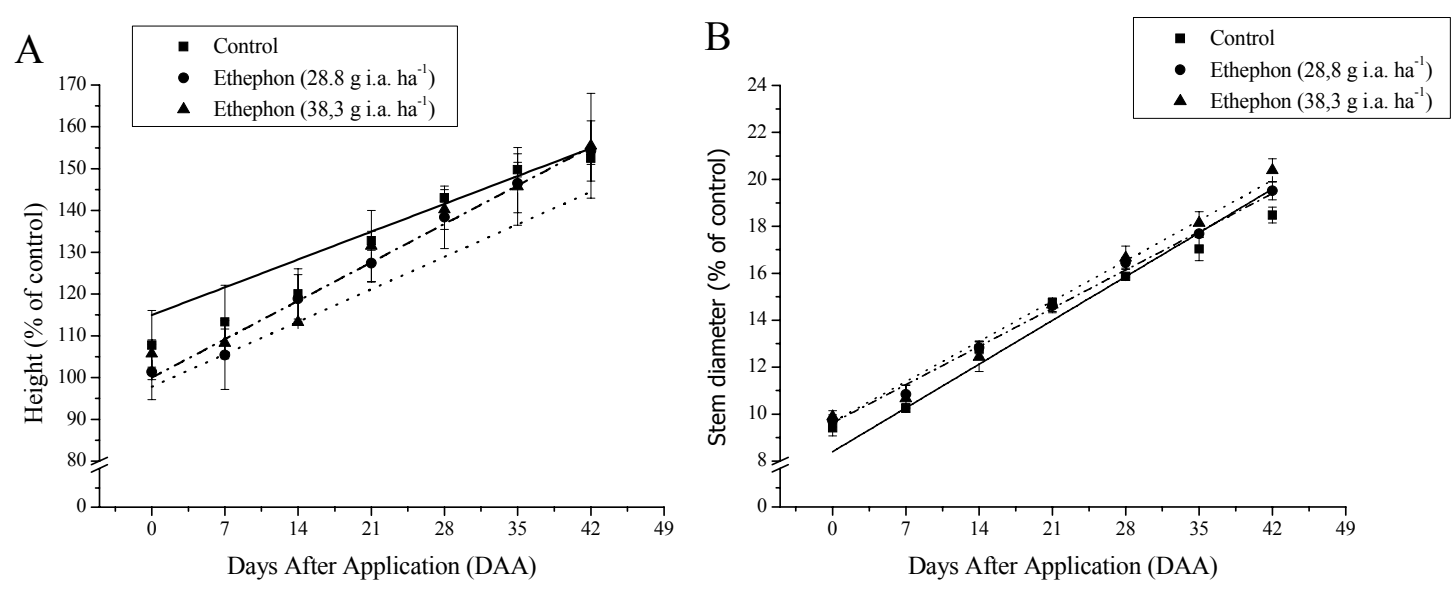

Figure 3. Effects of the different doses of ethephon on the height (A) and stem diameter (B) of eucalyptus seedlings up to 42 days after application (Jaboticabal, 2013)

Table 2. Parameters of the linear equation ( $\mathrm{a}$ e b) adjusted for treatment with ethephon, with a coefficient of determination $\left(\mathrm{R}^{2}\right)$ and $\mathrm{F}$ value for the regression analysis of variance (Jaboticabal, 2013)

\begin{tabular}{lcccc}
\hline Treatment & $\mathrm{a}$ & $\mathrm{b}$ & $\mathrm{R}^{2}$ & $\mathrm{~F}$ \\
\hline Height $(\mathrm{cm})$ & & & & \\
Control & $114.95 \pm 2.95$ & $0.95 \pm 0.09$ & 0.90 & $<0.001$ \\
Ethephon (28.8 g i.a. ha $\left.{ }^{-1}\right)$ & $100.0 \pm 4.57$ & $1.31 \pm 0.19$ & 0.99 & $<0.001$ \\
Ethephon (38,3 g i.a. ha $\left.{ }^{-1}\right)$ & $97.82 \pm 2.16$ & $1.11 \pm 0.15$ & 0.72 & 0.009 \\
\hline Stem diameter (mm) & & & & \\
Control & $8.40 \pm 0.03$ & $0.27 \pm 0.001$ & 0.99 & $<0.001$ \\
Ethephon (28.8 g i.a. ha $\left.{ }^{-1}\right)$ & $9.62 \pm 0.19$ & $0.23 \pm 0.006$ & 0.99 & $<0.001$ \\
Ethephon (38,3 g i.a. ha $\left.{ }^{-1}\right)$ & $9.67 \pm 0.22$ & $0.24 \pm 0.01$ & 0.99 & $<0.001$ \\
\hline
\end{tabular}

Obs: $\mathrm{a}=$ linear coefficient; $\mathrm{b}=$ angular coefficient of equation; $\mathrm{y}=\mathrm{a}+\mathrm{bx}$.

Comparing the effects of the different ethephon doses on the obtained increments, it can be seen that for the height, leaf area and leaf dry mass, there were no significant effects of the treatments. Although the different ethephon doses resulted in numerically higher values for the leaf area and leaf dry mass, the high variability portrayed by the standard error bar does not differentiate these treated plants from the untreated control (Figure 4).

A proportional increase in the stem diameter was observed from the ethephon application, regardless of the dose. However, when only the stem dry mass was assessed, the highest dose resulted in a significant increase, different from that of the control but not from that of the smaller dose. Consequently, no overall effects were observed for the total dry mass, for which only the highest dose resulted in an increase. 


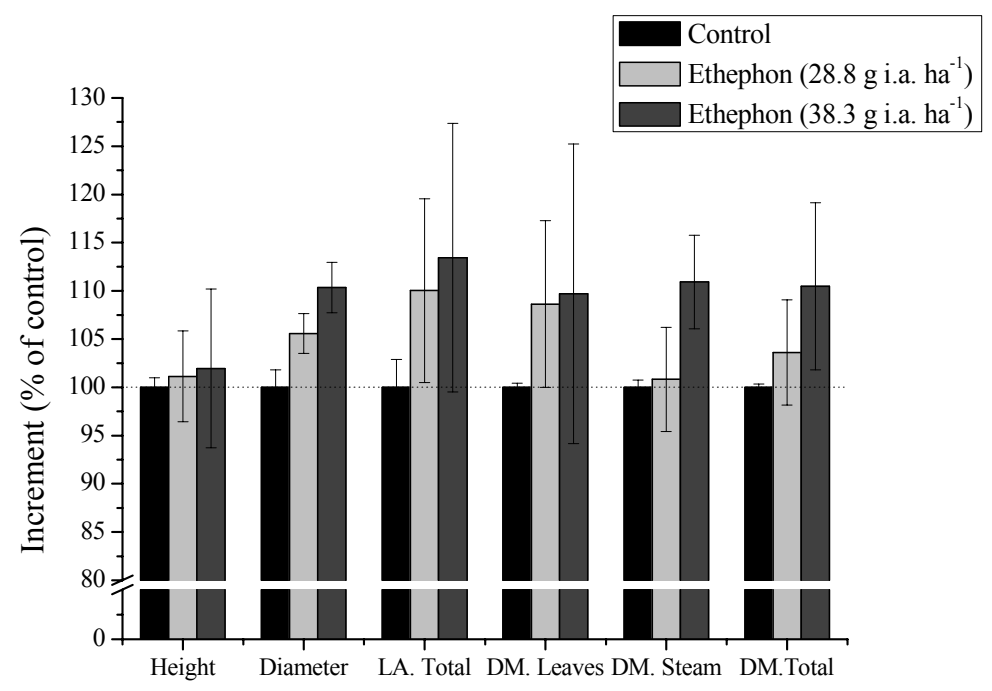

Figure 4. Effects of the different doses of ethephon on the height, stem diameter, leaf area and leaf, stem and total dry mass, expressed in percentage increments (Jaboticabal, 2013)

Ethephon is a phytoregulator that releases ethylene when it comes into contact with the plant and is characterized by promoting the senescence of leaves, flowers and fruits (Tomlin, 1994). The seedlings that were used in this experiment were in an early stage of development, and the likely effects caused by released ethylene were temporary. Additionally, the fact that the dose was small may have facilitated the metabolism of this ripener by the eucalyptus plants.

\subsection{Trinexapac-Ethyl}

The height of the plants was different between the different doses of applied trinexapac-ethyl and that of the control (Figure 5A). From the regression analysis (Table 3), it was found that the initial estimate for the height of the control plants $(2.95 \mathrm{~cm} \pm 114.95)$ was higher than that of the plants that were treated with trinexapac-ethyl, which did not differ among themselves, regardless of the dose $(99.20 \pm 2.71 \mathrm{~cm})$.

However, after the ripener application, the rate of height gain in the plants that were treated with trinexapac-ethyl, regardless of the dose $\left(0.95 \mathrm{~cm} \pm 0.09\right.$ day $\left.^{-1}\right)$, was higher than that of the control $\left(1.22 \mathrm{~cm} \pm 0.11\right.$ day $\left.^{-1}\right)$. As a result, 42 days after application, the height of all of the plants was equalized.

Regarding the stem diameter, a differential effect of the different doses of trinexapac-ethyl compared to that of the control (Figure 5B) was observed. From the regression analysis (Table 3), the estimated stem diameter for the plants at the beginning of the work was found to be different from that of the control plants, which presented a smaller diameter $(8.40 \pm 0.03 \mathrm{~mm})$ than the plants that were treated with trinexapac-ethyl, regardless of the dose $(10.54 \pm 0.41 \mathrm{~mm})$.

However, after treatment with trinexapac-ethyl, the increase in the diameter of the stem of the control plants $(0.27$ $\mathrm{mm}$ day $\left.^{-1}\right)$ was higher than that of the plants that were treated with the highest dose $\left(0.23 \mathrm{~mm} \mathrm{day}^{-1}\right)$, but it became equal to that of the lowest dose $\left(0.26 \mathrm{~mm} \mathrm{day}^{-1}\right)$, which was also greater than that of the highest dose.

As a result, 42 days after application, the stem diameter of the control plants remained smaller than that of the plants that were treated with the lowest dose of trinexapac-ethyl but equaled that of the plants that were treated with the highest dose. 

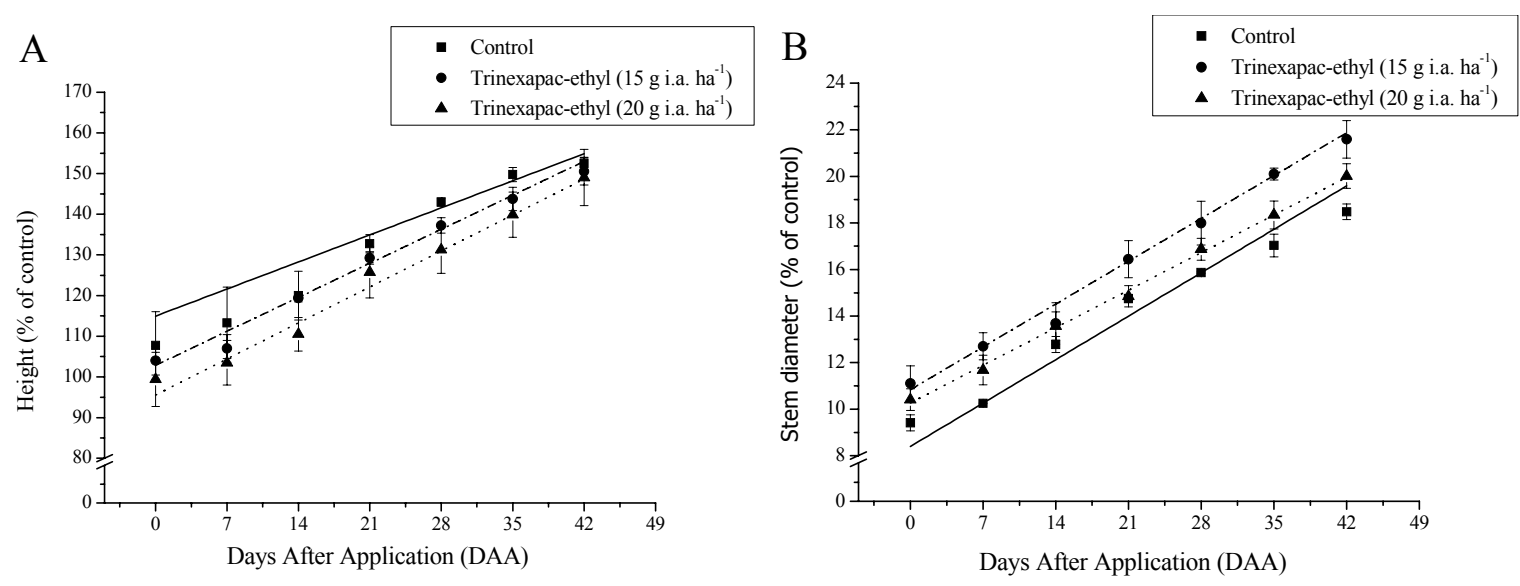

Figure 5. Effects of the different doses of trinexapac-ethyl on the height (A) and stem diameter (B) of eucalyptus seedlings up to 42 days after application (Jaboticabal, 2013)

Table 3. Parameters of the linear equation ( $\mathrm{e}$ b) adjusted for treatment with trinexapac-ethyl, with a coefficient of determination $\left(\mathrm{R}^{2}\right)$ and $\mathrm{F}$ value for the regression analysis of variance (Jaboticabal, 2013)

\begin{tabular}{|c|c|c|c|c|}
\hline Treatment & $\mathrm{a}$ & $\mathrm{b}$ & $\mathrm{R}^{2}$ & $\mathrm{~F}$ \\
\hline \multicolumn{5}{|l|}{ Height $(\mathrm{cm})$} \\
\hline Control & $114.95 \pm 2.95$ & $0.95 \pm 0.09$ & 0.90 & $<0.001$ \\
\hline Trinexapac-ethyl (15 g i.a. ha $\left.^{-1}\right)$ & $102.84 \pm 1.50$ & $1.19 \pm 0.07$ & 0.98 & $<0.001$ \\
\hline Trinexapac-ethyl (20 g i.a. ha $\left.^{-1}\right)$ & $95.56 \pm 3.93$ & $1.26 \pm 0.16$ & 0.97 & $<0.001$ \\
\hline \multicolumn{5}{|l|}{ Stem diameter $(\mathrm{mm})$} \\
\hline Control & $8.40 \pm 0.03$ & $0.27 \pm 0.001$ & 0.99 & $<0.001$ \\
\hline Trinexapac-ethyl (15 g i.a. ha $\left.^{-1}\right)$ & $10.83 \pm 0.47$ & $0.26 \pm 0.01$ & 0.99 & $<0.001$ \\
\hline Trinexapac-ethyl (20 g i.a. ha $\left.{ }^{-1}\right)$ & $10.26 \pm 0.35$ & $0.23 \pm 0.01$ & 0.99 & $<0.001$ \\
\hline
\end{tabular}

Obs: $a=$ linear coefficient; $b=$ angular coefficient of equation; $y=a+b x$.

Comparing the effects of the different doses of trinexapac-ethyl, the stem diameter from the treatment with the lower dose of trinexapac-ethyl resulted in a higher growth rate compared to that of the lower dose of ripener, which tended to develop intermediately, and that of the control (Figure 6). Regarding the plant height and stem dry weight, no effects were detected regarding the behavior between the different doses of trinexapac-ethyl and the control (Figure 6).

Regarding the total leaf area and leaf dry weight, both of the ripener treatments produced a significant increase compared to that of the control (Figure 6). For the total dry mass, the treatment with the highest dose of trinexapac-ethyl did not promote growth; however, the treatment with the lowest dose of ripener produced an increase in the growth rate compared to that of the control (Figure 6). 


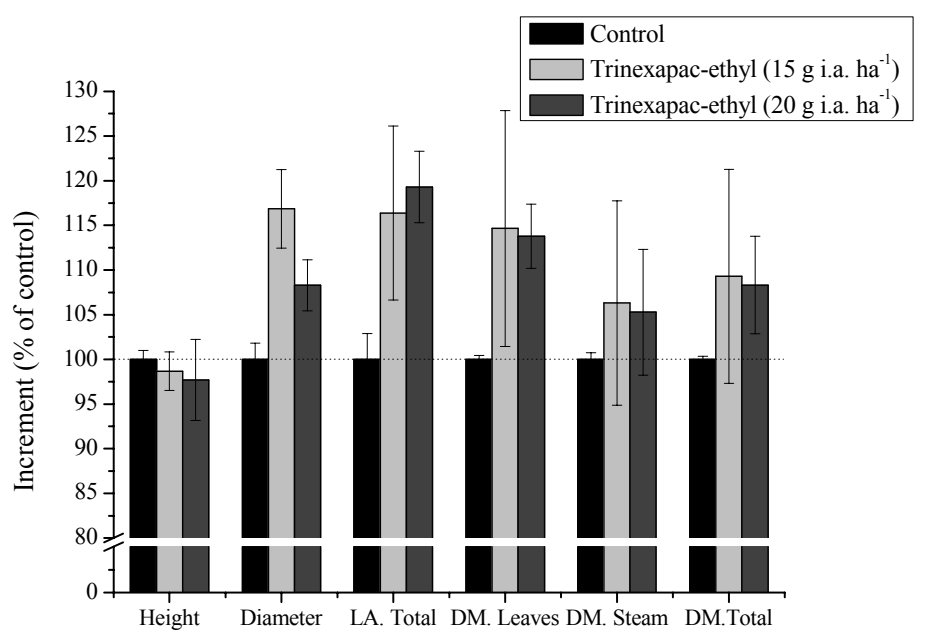

Figure 6. Effect of the different doses of trinexapac-ethyl on the height, stem diameter, leaf area and leaf, stem, and total dry mass, expressed in percentage increments (Jaboticabal, 2013)

Trinexapac-ethyl is used in the cultivation of sugarcane as a plant growth regulator that causes the inhibition or reduction of the growth rate to reduce plant height and prevent lodging (Amrein, Rufener, Quadranti, 1989).

The ripener is involved in the inhibition of biosynthesis of active gibberellic acid (GA1, GA20), which is in turn responsible for the processes of cell division and elongation. However, as noted, the application of trinexapac-ethyl resulted in an increasing trend in the growth rate of eucalyptus plants (Figure 5A); along with an expansion of the total leaf area and an increase in the leaf dry weight (Figure 6).

Trinexapac-ethyl is a ripener that does not compromise the integrity of the apical bud, but it may promote the loss of dominance of that bud and does not affect the photosynthesis process, which may have caused the increase in the leaf dry mass and the total leaf area expansion observed in this study.

\section{Conclusions}

The application of sub-doses of sulfometuron-methyl ( 0.9 and $\left.1.2 \mathrm{~g}^{\text {i.a. ha }}{ }^{-1}\right)$, ethephon (28.8 and $\left.38.3 \mathrm{~g}^{\text {i.a. ha }}{ }^{-1}\right)$ and ethyl-trinexapac (15 and $20 \mathrm{~g}$ i.a. $\mathrm{ha}^{-1}$ ) did not cause deleterious effects on the growth of Eucalyptus urograndis until 42 days after application (DAA).

The application of sulfometuron-methyl may have generated the effect known as "hormesis" due to an increasing trend in the growth of eucalyptus seedlings.

The application of trinexapac-ethyl resulted in greater increases in the leaf dry mass and total leaf area for both doses.

\section{References}

Abraf-Associação Brasileira Dos Produtores De Florestas Plantas. Anuário estatístico da ABRAF: ano base. (2012 \& 2013). Retrieved August 10, 2013, from www.abraflor.org.br/estatisticas.asp

Amrein, J., Rufener, M., \& Quadranti, M. (1989). The use of CGA 163'935 as a growth regulator in cereals and oilseed rape. In Brighton Crop Protection Conference - Weeds Switzerland (pp. 2-12), Ciba Geigy, Switzerland.

Andef-Associação Nacional de Defesa Vegetal. (2004). Manual de tecnologia de aplicação de produtos fitossanitários. Campinas: Linea Criativa.

Bukowski, J. A., \& Lewis, R. J. (2000). Hormesis and health: A little of what you fancy may be good for you. Southern Medical Journal, 93, 371-374. http://dx.doi.org/10.1080/15401420490426927

Calabrese, E. J. (2005). Paradigm lost, paradigm found: The reemergence of hormesis as a fundamental dose response model in the toxicological sciences. Geneva, Environ. Pollution, 138, 378-411. http://dx.doi.org/10.1016/j.envpol.2004.10.001

Calabrese, E. J., \& Baldwin, L. A. (2001). Hormesis: U-shaped dose responses and their centrality in toxicology. Trends in Pharmacological Science, 22, 285-291. http://dx.doi.org/10.1016/S0165-6147(00)01719-3 
Calabrese, E. J., \& Baldwin, L. A. (2002). Applications of hormesis in toxicology, risk assessment and chemotherapeutics. Trends Pharmacology, 7, 323-331. http://dx.doi.org/10.1016/S0165-6147(02)02034-5

Cedergreen, N. (2008). Herbicides can stimulate plant growth. Weed Research, 48(5), 429-438. http://dx.doi.org/10.1111/j.1365-3180.2008.00646.x

Cedergreen, N., Streibig, J. C., Kudsk, P. Mathiassen, S. K., \& Duke, S. O. (2007). The occurrence of hormesis in plants and algae. Dose-Response, 5(2), 150-162. http://dx.doi.org/10.2203/dose-response.06-008

Conab-Companhia Nacional de Abastecimento, Série histórica. Comparativo de área, produção e produtividade. Retrieved from http://www.conab.gov.br. Acesso em: 10 Ago. 2013

Duke, E. O., Cedergreen, N., Velini, E. D., \& Belz, R. G. (2006). Hormesis: is it an important factor in herbicide use and allelopathy? Outlooks on Pest Management, 17(1), 29-33. http:// dx.doi.org/10.1564/16feb10

Durigan, J. C. (1989). Comportamento de herbicidas no ambiente. In Seminário Técnico sobre plantas daninhas e o uso de herbicidas em reflorestamento, Rio de Janeiro. Anais... Rio de Janeiro: SBS/ABRACAV/SIF.

Tomilin, C. (1994). The pesticide manual (10th ed., p. 1341). Cambrige: Crop Protection.

Tonini, H., Schneider, P. R., \& Finger, C. A. G. (2004). Crescimento de clones de Eucalyptus saligna Smith, na Depressão Central e Serra do Sudoeste, Rio Grande do Sul. Ciência florestal, Santa Maria, 14(2), 61-77.

Velini, E. D., Alves, E., Godoy, M. C., Meschede, D. K., Souza, R. T., \& Duke, S. O. (2008). Glyphosate applied at low doses can stimulate plant growth. Pest Management Science, 64(2), 489-496. http://dx.doi.org/10.1002/ps.1562

Velini, E. D., Trindade, M. L. B., Barberis, L. R. M., \& Duke, S. O. (2010). Growth regulation and other secondary effects of herbicides. Weed Science, 58(3), 351-354. http://dx.doi.org/10.1614/WS-D-09-00028.1

Vidal, R. A. (1997). Herbicidas: Mecanismos de ação e resistência de plantas. Porto Alegre, RS, 165.

\section{Copyrights}

Copyright for this article is retained by the author(s), with first publication rights granted to the journal.

This is an open-access article distributed under the terms and conditions of the Creative Commons Attribution license (http://creativecommons.org/licenses/by/3.0/). 